\title{
The Role of National Energy Policies and Life Cycle Emissions of PV Systems in Reducing Global Net Emissions of Greenhouse Gases
}

\author{
Gabriel Constantino de Lima ${ }^{1}\left[\right.$, Andre Luiz Lopes Toledo ${ }^{1, *(\mathbb{C}}$ and Leonidas Bourikas ${ }^{2}$ (D) \\ 1 Federal Institute of Education, Science and Technology (IFRN), Natal 59015-000, Brazil; \\ gabriel.constantino@ifrn.edu.br \\ 2 School of Architecture, Imagination Lancaster, LICA, Lancaster University, Lancaster LA1 4YW, UK; \\ 1.bourikas@lancaster.ac.uk \\ * Correspondence: andre.lopes@ifrn.edu.br; Tel.: +55(84)99129-2957
}

Citation: Lima, G.C.d.; Toledo, A.L.L.; Bourikas, L. The Role of National Energy Policies and Life Cycle Emissions of PV Systems in Reducing Global Net Emissions of Greenhouse Gases. Energies 2021, 14 , 961. https://doi.org/10.3390/ en14040961

Academic Editor: Gregorio García

Received: 5 January 2021

Accepted: 6 February 2021

Published: 11 February 2021

Publisher's Note: MDPI stays neutral with regard to jurisdictional claims in published maps and institutional affiliations.

Copyright: (c) 2021 by the authors. Licensee MDPI, Basel, Switzerland. This article is an open access article distributed under the terms and conditions of the Creative Commons Attribution (CC BY) license (https:// creativecommons.org/licenses/by/ $4.0 /)$.

\begin{abstract}
The energy sector and electricity generation in particular, is responsible for a great share of the global greenhouse gas (GHG) emissions. World electricity generation is still largely based on the burning of fossil fuels. However, Brazil has already a very low electricity carbon intensity due to the country's large hydropower capacity. In countries with low grid carbon intensities such as Brazil, the investment in photovoltaic solar systems (PVSS) even if it is cost-effective, might become challenging as any new generation competes essentially against other renewable generation and the carbon offset is not a key driver for investment anymore. This study builds further upon that case to examine if national renewable energy incentives could actually lead to an increase of global net carbon emissions from the installation of PVSS in countries with a low grid carbon intensity. The study presents a life cycle analysis (LCA) of ten photovoltaic systems representative of the different operational conditions in regions across Brazil. It was found that the average energy payback time of the studied PV plants is between 3 and 5 years of operation. This result shows the feasibility and viability of such investments in the Brazilian context. When the LCA was integrated into the analysis though, the results showed that the "local" direct emissions avoidance from two out of ten studied PV plants would not manage to offset their "global" life cycle emissions due to the 2020 projected Brazilian grid emission factor which is already low. It is important to recognize that public policies of unrestricted, unconditional stimulus to photovoltaic systems investment might not help towards reducing global net emissions when the PV systems are installed at countries with a low carbon emission electric matrix. That is also something to consider for other countries as the carbon intensity of their grids will start reducing at levels similar to Brazil's. It is likely that in the near future, the real net carbon offset achieved by PV systems at the global level will be largely defined by the manufacture procedures and the production's carbon intensity at the country of origin of the PV panels.
\end{abstract}

Keywords: life cycle assessment (LCA); renewable energy; photovoltaics; greenhouse gas emission rate (GHGe-rate); embodied carbon; net-zero emissions

\section{Introduction}

The energy sector is responsible for more than $70 \%$ of global Greenhouse Gas (GHG) emissions. Within the energy sector, the largest part of global energy consumption is associated with electricity generation (5485 millions tons of $\mathrm{CO}_{2-\text { eq }}$ Mtoe in comparison with 2891 Mtoe for transport) [1]. Despite the investments and increasing trend in renewable power generation capacity (total $2351 \mathrm{GW}$ in 2019), world electricity generation still relied on coal (36\% of generation) and gas power plants. In fact, the capacity of coal fired power plants (38.5\% of global power mix) has doubled (from 1066 to $2045 \mathrm{GW}$ ) between 2000 and 2019 but the increase rate has reduced drastically the last years [2]. 
As expected, neither the energy demand nor the associated emissions and efficiency are equally distributed among countries. Most countries with high per capita gross domestic product (GDP) still have high per capita energy use. It is however important that this trend is not repeated in the case of the carbon emission intensity $\left(\mathrm{kg} \mathrm{CO}_{2}\right.$ per output of economy in \$) of their economies. The countries with the highest GDP per capita have largely managed to reduce the carbon intensity of their GDP, mainly through increased efficiency and a shift from industrial production to services. Whereas the countries with the lowest GDP per capita, mostly in Africa, are likely to have a low carbon emission intensity due to the small scale of energy consumption and production. Brazil in particular, while it is among the ten countries with the highest GDP globally, it has a medium to high GDP per capita and a carbon intensity of $0.16 \mathrm{~kg}$ per $\$$ (2017 PPP, 2016 data) comparable to $0.26 \mathrm{~kg}$ per \$ in the United States, $0.13 \mathrm{~kg}$ per \$ in the United Kingdom, $0.3 \mathrm{~kg}$ per \$ in India, and $0.5 \mathrm{~kg}$ per $\$$ in China [3]. From this list, the UK is probably a good example of the shift from manufacture towards services and investment in renewable energy sources in comparison with India and China which are currently the epicenter of industrial production and they still rely on coal. This is also depicted by the electricity grid carbon intensity $\left(\mathrm{kg} \mathrm{CO}_{2 \mathrm{e}}\right.$ per $\mathrm{kWh}_{\mathrm{e}}$ ) of these countries, with the UK emitting $0.28 \mathrm{~kg} \mathrm{CO}_{2 \mathrm{e}} / \mathrm{kWh}_{\mathrm{e}}$ (2017), the US on average $0.48 \mathrm{~kg} \mathrm{CO} 2 \mathrm{e} / \mathrm{kWh}_{\mathrm{e}}$ (2016), India $0.74 \mathrm{~kg} \mathrm{CO} 2 \mathrm{e} / \mathrm{kWh}_{\mathrm{e}}$ (2017), China $0.62 \mathrm{~kg}$ $\mathrm{CO}_{2 \mathrm{e}} / \mathrm{kWh}_{\mathrm{e}}$ (2017), and Brazil $0.09 \mathrm{~kg} \mathrm{CO}_{2 \mathrm{e}} / \mathrm{kWh}_{\mathrm{e}}$ (2017), respectively [4].

Brazil has already a very low electricity carbon intensity due to the country's large hydropower capacity which is the second largest (109 GW) in the world after China [5]. In this case, interventions to reduce carbon emissions would likely focus on the agriculture and transportation and not the energy sector. It becomes apparent that in countries with low grid carbon intensities such as Brazil, the investment in photovoltaic solar systems (PVSS), even if it is cost-effective, might become challenging as any new electricity generation competes essentially against other renewable generation and the carbon offset is not a key driver for investment anymore.

Figure 1 shows the contribution of each sector of the economy in the total emissions of Brazil and a detailed breakdown of the energy sector emissions.

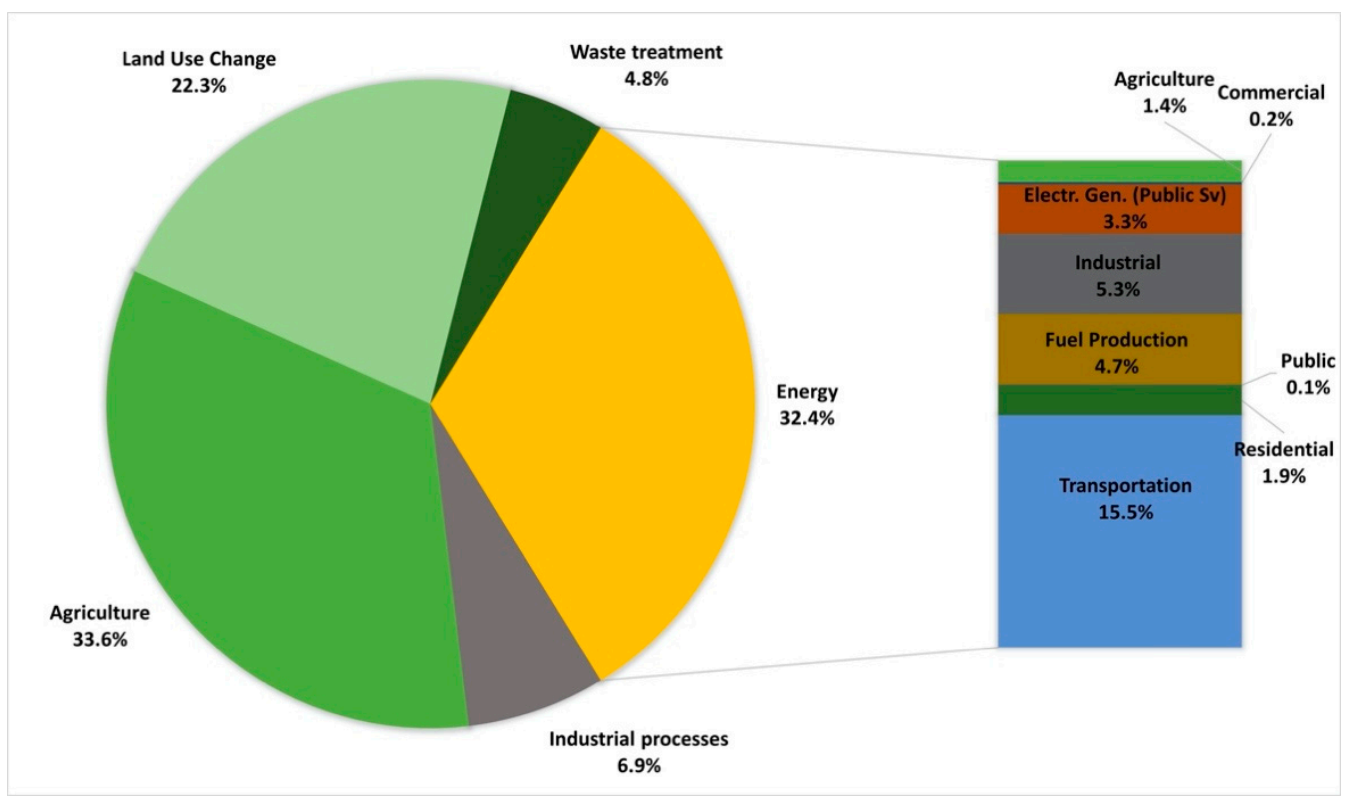

Figure 1. Total net emissions in 2016-1305.6 million tons of $\mathrm{CO}_{2-\mathrm{eq}}$. Data Source: [6,7].

This study builds upon this case to examine if there could actually be an increase of net carbon emissions from the installation of PVSS in countries with a low grid carbon intensity. Data were gathered from ten operational PV power plants in Brazil and a life cycle assessment of the PV modules was performed to investigate the embodied carbon in 
PVSS and the conditions under which their installation could still help reduce the country's electricity related carbon emissions. Electricity generation output, the location and technical specifications of the studied PV plants were collected with the written permission of SMA Brazil from the Sunny Portal website.

\subsection{Energy Matrix and Greenhouse Gas Emission Factors}

World electricity generation is still largely based on the burning of fossil fuels (Figure 2). According to the International Energy Agency (IEA) consolidated world power matrix as shown in Figure 2, 64\% of world electricity generation comes from coal, natural gas, and diesel-fired power plants [8].

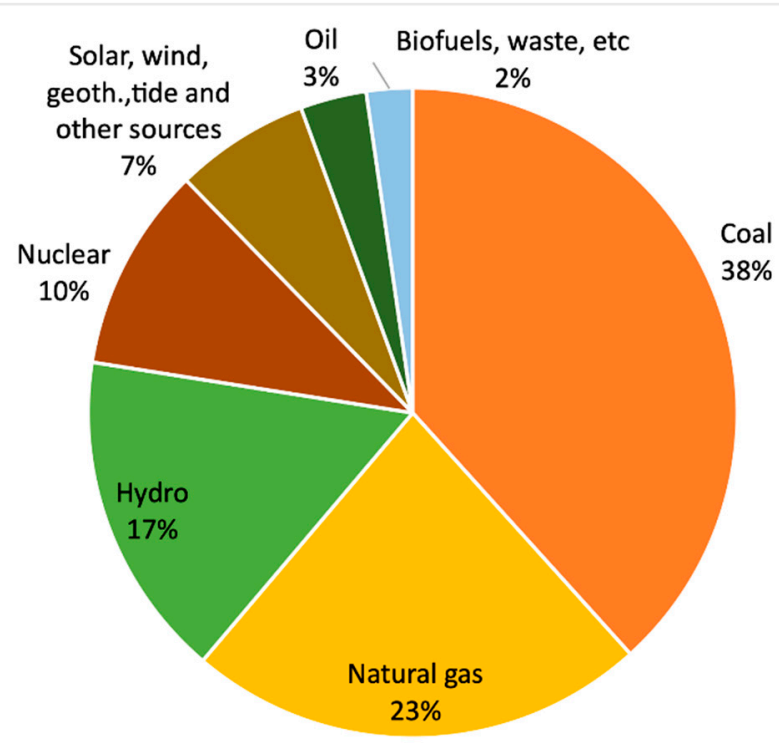

Figure 2. World electricity matrix in 2017. Data Source: [8].

As expected, national electricity generation mixes depend mainly on the conditions of each country's access to energy resources. Countries with large natural reserves of oil, coal, and natural gas, found in the use of these resources the opportunity to power their industrialization and urbanization as these were relatively cheaper than other sources and easier to exploit. This historical use of energy resources is reflected in the electricity sector emission factors, which vary across countries widely. The average global electricity emission factor, also known as carbon intensity of electricity, was $485 \mathrm{~g} \mathrm{CO}_{2} / \mathrm{kWh}$ in 2017, whereas China emitted on average $637 \mathrm{~g} \mathrm{CO}_{2} / \mathrm{kWh}$ between 2015 and 2017 [9]. Although China has excelled in its efforts to decarbonize its own energy matrix, it is still investing heavily in coal-fired power projects in Asia, which maintains the trend of high emission factors in the region (Figure 3) [4].

By contrast, Brazil's electricity is mainly generated by renewable sources, in particular, hydropower (70\% of total generation). Its emission factor in 2018 was only $74 \mathrm{~g} \mathrm{CO}_{2} / \mathrm{kWh}$, or about 6 times less than the world average [11]. The development plan for the Brazilian electricity sector is presented in the Decennial Energy Plan-PDE 2027 [12] which, together with the forecast of demand growth, incorporates actions to meet national carbon emission reduction commitments. These actions include the recent expansion of the wind sector and energy efficiency improvement programs. Figure 4 presents the Brazilian electricity matrix in 2017 and the PDE forecasts for 2022 and 2027 [12], maintaining the strong share of renewable sources. 


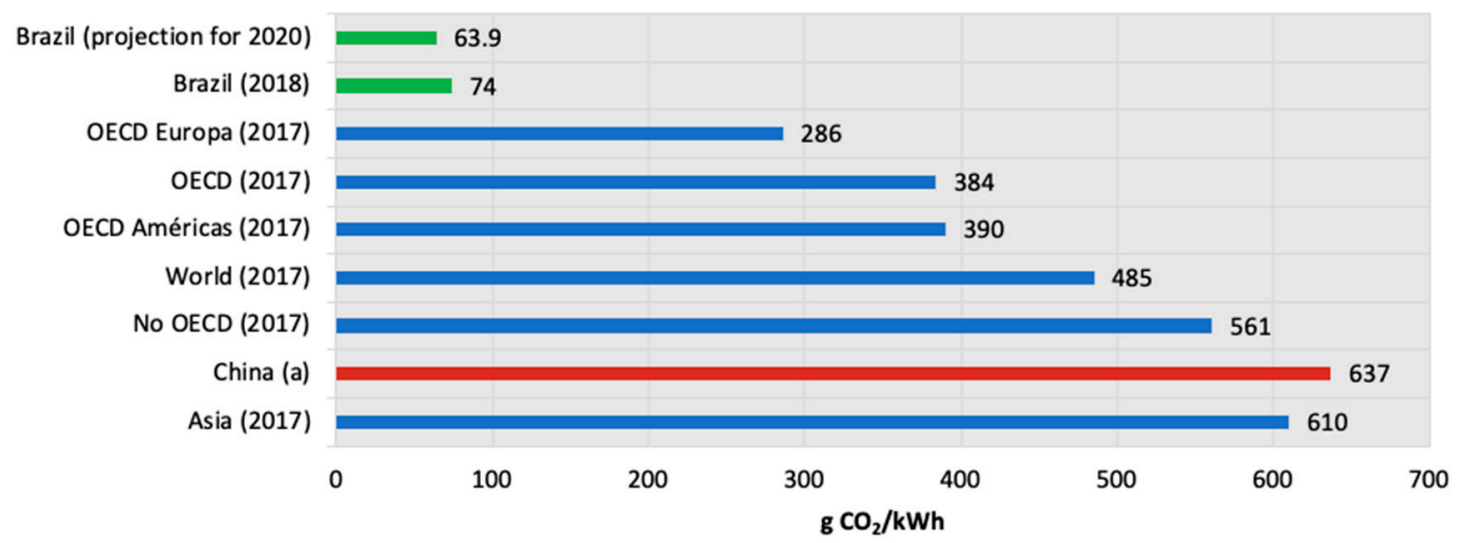

Figure 3. Average electricity emission factors for the period 2015-2018. Data Source: [9-11]. Note: (a) the average value of the IEA in the years 2015 and 2017 [9].
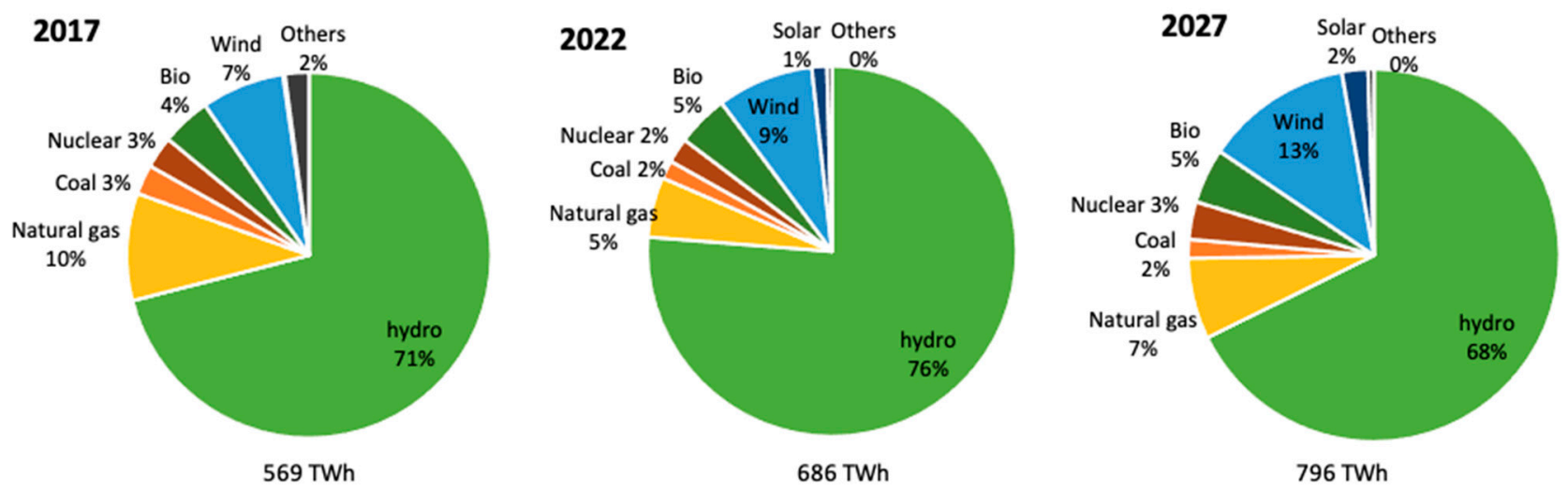

Figure 4. Decennial energy plans for the evolution of the Brazilian electrical matrix installed capacity by generation source. Data Source: [12]. Note: The data refer to the centralized internal supply of electricity excluding any distributed generation and self-production.

Figure 4 shows that the forecasted mix remains unchanged with small changes in hydropower capacity offset by a small increase mainly in wind power capacity. The direct consequence of the large share of hydropower in the Brazilian electricity matrix is the low emission factor of the electricity sector and the maintenance of this low factor in the scenarios for the next decade. Figure 5 shows the history of emission factors from 2006 to 2019 [11], with a projected rate of $63.9 \mathrm{~g} \mathrm{CO}_{2} / \mathrm{kWh}$ for 2020 [10].

Dale et al. [13] and Projeto Balcar [14] comment on the reasonable uncertainty about the quantification of net GHG emissions from artificial reservoirs. An extensive study of the Carbon Balance in Hydroelectric Reservoirs was carried out by Projeto Balcar [14] in the period from 2011 to 2013. The project was a collaboration of the Eletrobras group and ten Brazilian research institutions and it made a detailed analysis of biota and gas exchange over the period of one year in 11 Brazilian hydroelectric plants. The results indicated positive net emissions in some and negative in others. More extensive studies are needed to determine the carbon balance of the more than 140 Brazilian hydroelectric plants linked to the National Interconnected System (NIS).

In a study developed by Barros et al. [15], the authors work on the projections of electricity supply as electricity elaborated by EPE in PDE2026 [16], using data from Ecoinvent [17]. In their report, they point out that the GHG emission rates associated with each type of technology used for electricity generation. The NIS emission rate was found to be $0.205 \mathrm{~kg} \mathrm{CO}$ 2-eq $/ \mathrm{kWh}$ which is different from the official data provided by the Brazilian government. However, in relation to the Brazilian NIS emission factor, and in the absence 
of a comprehensive study on net emissions from Brazilian hydroelectric dams, this study used for the calculations the official data from the Brazilian government, provided by the Ministry of Science, Technology, Innovation, and Communication (MCTIC) [11].

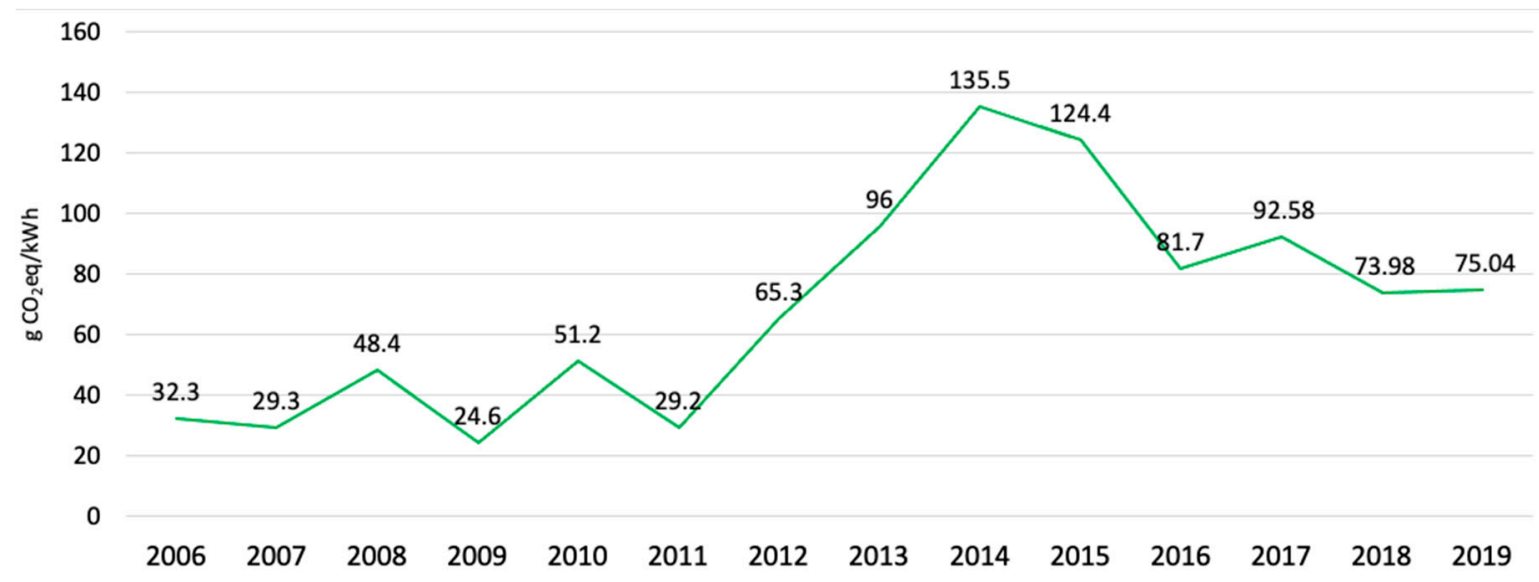

Figure 5. Evolution of Brazilian electricity emission factors in $\mathrm{g} \mathrm{CO}_{2} / \mathrm{kWh}$ (2006-2019). Data Source [11].

The significant increase registered in the emission factor of the Brazilian electric matrix for the years from 2012 to 2015 can be attributed to the greater use of thermoelectric plants during this period. These plants have a strategic function of serving as a reserve to be used when hydroelectric plants are unable to meet demand. In that period, the backup generation was put into operation due to low levels at the water reservoirs as a result of prolonged drought periods.

Maintaining a low power matrix emission factor is in line with the national determined contributions (NDCs) undertaken by Brazil under the Paris Agreement, with a target to reduce $\mathrm{GHG}$ emissions by 37\% (1.3 $\mathrm{Gt} \mathrm{CO}_{2 \text {-eq. }}$ ) by 2025 and by $43 \%$ (1.2 $\mathrm{Gt} \mathrm{CO}_{2 \text {-eq. }}$ ) by 2030 in relation to the 2005 baseline emissions (total of $2.1 \mathrm{Gt} \mathrm{CO}_{2-\mathrm{eq}}$ ), using the global warming potential-GWP-100 metric (IPCC AR5) [18].

\subsection{Public Policy to Incentivise Distributed Renewable Generation}

In 2012, Normative Resolution No. 482 (REN 482/2012) [19] defined the regulatory framework for distributed generation (DG) in Brazil and it has been important to the evolution of DG in the country. Subsequently, ANEEL (Brazilian Electricity Regulatory Agency) made robust changes through REN 687/2015 and REN 786/2017 [20,21]. The main changes were: (1) the establishment of remote self-consumption and shared generation modalities; (2) the possibility of offsetting energy credits between headquarters and branches of the same business groups; (3) condominium distributed generation systems (individuals and companies); (4) the expansion of the power of photovoltaic systems from $1 \mathrm{MW}$ to $5 \mathrm{MW}$; and (5) the extension of possibility of use (credits) of electricity from 3 years to 5 years. According to this legislation, microgeneration refers to any power plant which relies on a qualified cogeneration or renewable energy sources with a maximum installed capacity of $75 \mathrm{~kW}$ that is connected to the central distribution network. Similarly, mini generation refers to power plants with installed capacity of $75 \mathrm{~kW}$ and up to $5 \mathrm{MW}$ for qualified cogeneration and renewables, as regulated by ANEEL [22]. ANEEL credits the significant growth in the number of micro and mini generator connections in Brazil to the evolution of DG regulation in the country. DG capacity has grown approximately 31 times between 2014 and 2016, increasing the number of connections from 284 to 8842 connections. In the scenarios presented by EPE, there are not any significant negative impacts associated with the expansion of the distributed generation network [12]. A frank and progressive expansion with micro and distributed mini generators that has been intensifying since 2016 [22]. According to Greener [23], the favorable regulatory model, associated with the cost reduction of the micro and mini generation distributed (MMDG) technologies 
allowed the consumer to evolve from a passive to an active position in the electricity sector. EPE indicates that in 2027, there will be 1.35 million adopters of MMGD systems, totaling 11.9 GW capacity mostly from solar energy [12].

Regarding the financial return on electricity production, two practices are discussed: (1) the feed-in tariff (FIT), or payment for renewable energy, in which long-term contracts are made with a producer; or (2) net metering, where an electric energy compensation system for consumers-generators, also called prosumers, is established. The exported electricity is being deducted from the prosumers' accounts and they pay the difference between the generated and consumed electricity [24]. According to Pinto and Zilles [25], the reason for adopting net metering policies in the country instead of FITs is that network parity has already been achieved in most areas of Brazil. That is, alternative energy sources would have already reached a level energy cost less than or equal to the direct purchase price from the grid.

\section{Life Cycle Assessment of Solar Photovoltaic Systems}

The life cycle assessment (LCA) methodology is generally used as a technique to measure and analyze energy use and its environmental impacts arising from product development throughout its life cycle [26]. According to Löfgren et al. [27], the concept of LCA must be considered in modern industrial environmental management, which implies that emissions and the use of resources are considered both in the company's production processes and the environmental impacts related to the life cycle of its products. LCA is characterized by conducting a systematic and efficient analysis of the environmental impacts related to a product, process, or economic activity, surveying and measuring the impacts of the energy and material resources demanded in addition to the waste released to the environment. The LCA methodology is a comprehensive and structured quantification of material and energy flows. This structuring of flows also allows the quantification of emissions during the life cycle of products or processes, which are standardized by ISO 14040 and 14044.

A complete life cycle assessment also includes the environmental impact caused by all inputs and outputs of a process or product [28,29]. The renewable energies wind and solar photovoltaic, according to the critical review that considered 47 studies, have the lowest impacts on carbon emissions and consequent global warming, compared to other technologies. [30]. Our study has also identified the Ecoinvent database as the most used amongst the 47 publications in the literature review.

IEA [31] grouped guidelines that constitute a consensus among LCA PV experts from Europe, the United States, and Asia, providing guidance on consistency, criteria, and quality, aiming to improve the credibility of LCA findings for photovoltaic systems (PVSS) by guiding methods and results reports, reinforcing the relevance of these studies on the world stage.

\subsection{LCA Methodology}

The following are the Equations (1), (2), and (3) that were used in the study to calculate indicators: Energy payback time (EPBT), greenhouse gas emission rate (GHGe-rate), and payback time emission, were used to assess the environmental performance of PVSS. The terms present in these equations are described in the table right after the equations.

- Energy payback time (EPBT), given by the following equation [26,32]:

$$
\mathrm{EPBT}=\frac{\mathrm{CED}}{\mathrm{E}_{\mathrm{agen}} / \mathrm{ng}}
$$

- Greenhouse gas emission rate (GHGe-rate), given by the following equation [26]:

$$
\mathrm{GHGe}_{\text {rate }}=\frac{\text { GHGe_total }}{\text { EE }_{\text {LCA_output }}} \text {. }
$$


$\mathrm{CED}=\mathrm{E}_{\text {input }}+\mathrm{E}_{\mathrm{BOS}}$

Eagen

ng

Einput

$\mathrm{E}_{\mathrm{BOS}}$

GHGe-rate

GHGe-total

EE $E_{\text {LCA-output }}$

Payback Time Emission
- Payback time emission, given by the following equation:

$$
\text { Payback time emission }=\frac{\text { Generated emissions }}{\left(\frac{\text { avoided emissions during lifetime }}{\text { lifetime }}\right)} \text {. }
$$

where:

CED (cumulative energy demand) is the sum of $E_{\text {input }}$ : primary energy entering the life cycle (MJp) and the $\mathrm{E}_{\mathrm{BOS}}$ : energy required by the balance of system (BOS) (MJp).

annual electricity generation by the PVSS (MJ).

average conversion rate of primary energy into grid electricity in the country where the panel is installed.

includes the energy required for module manufacturing, transportation, installation, operation, and maintenance, and its final decommissioning or recycling.

is the energy required for BOS components, including support structure, cabling, electronic and electrical components, inverters, and batteries for standard isolated systems.

is the GHG emission rate per unit of electricity generated by the PVSS ( $\mathrm{g} \mathrm{CO}_{2-\mathrm{eq}} / \mathrm{kWh}$ ).

comprises the total GHG emissions during the life cycle $\left(\mathrm{g} \mathrm{CO}_{2-\mathrm{eq}}\right)$.

is the total electricity generated by the PVSS during the life cycle (kWh).

indicates how many PVSS years of operation will be required to offset the emissions generated during the manufacturing and installation process (Equation (3)).

The following, Figure 6, presents an overview of the data flow used in this study.

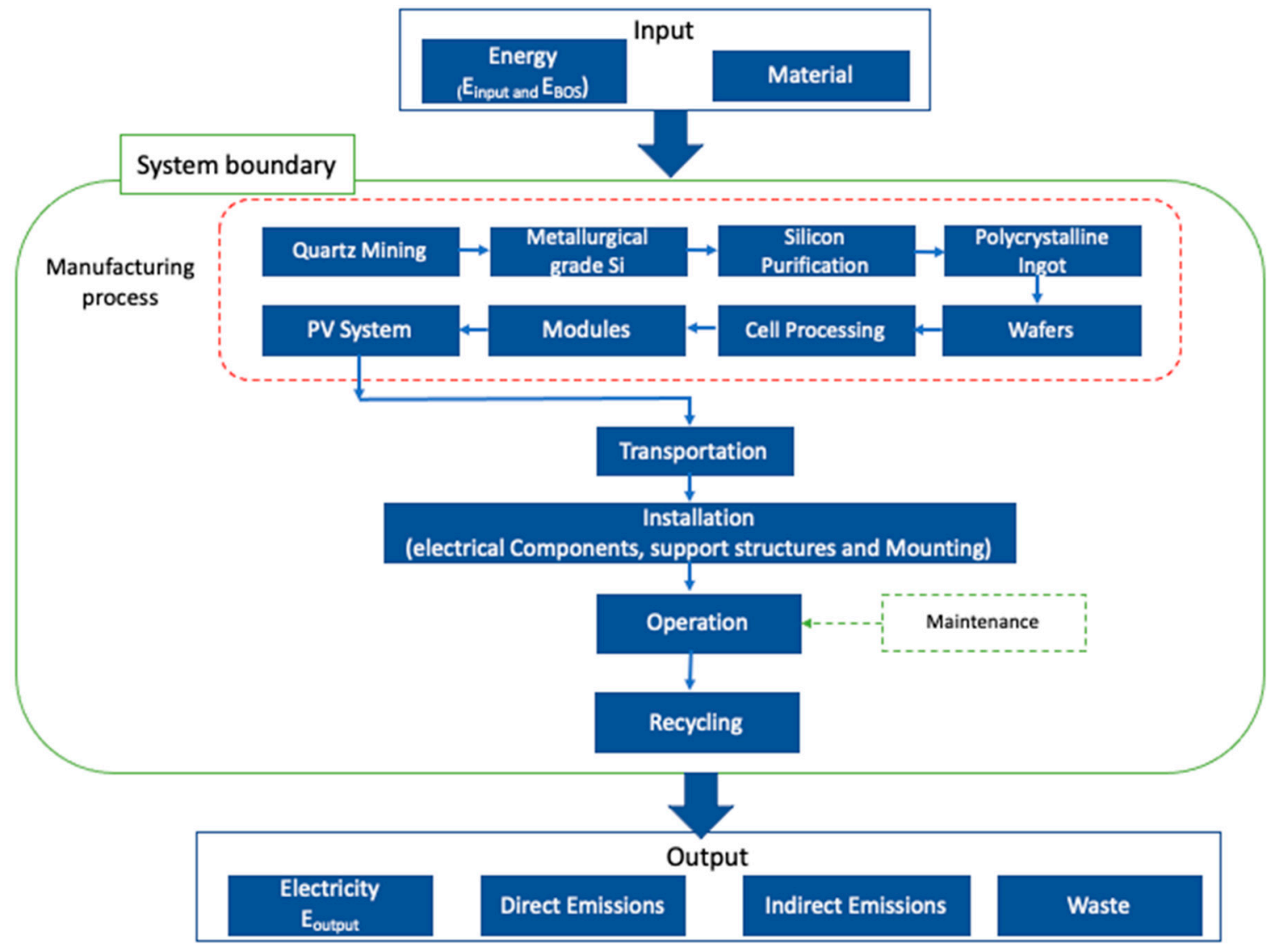

Figure 6. System boundary for the PVSS LCA in this study.

A complete quantitative and qualitative analysis of the energy generated by the PVSS, must consider its possible environmental impacts and its contributions to net GHG emissions. Therefore, it is essential that several factors in the life cycle analysis are considered, such as: type of PV panels, efficiency ratings, manufacturing technology, assembly pattern, 
matrix support, absent or present structure, installation location (facade, roof, or floor), type of connection (grid or insulated), and performance rate, including all losses [26,33].

The precision and high time resolution of energy consumption data is expected to have a noticeable impact on the precision of the results of the LCA study. Typically, PVSS in a domestic setting have an installed capacity of less than $5 \mathrm{~kW}$ and they are connected in a single string with an inverter. Batteries are not commonly part of these systems and the system is connected with the main grid.

\subsection{System Boundaries}

This study collected the electricity generation data from ten solar photovoltaic systems (PVSS), in operation for the period of one year in 2018 with a total installed capacity of $845 \mathrm{~kW}_{\mathrm{p}}$. The examined systems are located in different regions of Brazil.

PV commercial technology had a remarkable increase in efficiency the last 30 years followed by an impressive reduction of cost per $\mathrm{kW}$ installed capacity. It is likely that the further development of PV panels with efficiency above 20-24\% at comparable costs could be achieved with economies of scale in the next decade. An important factor to the pace of PVSS upgrades will likely be the contracts and maintenance deal the solar farms have in place, the cost effectiveness of more efficient panels and their operational costs but also, once again as the paper discusses, the carbon intensity of future PV panel manufacture and distribution regardless of the technology used.

The system boundaries and the assumptions that were made in this study:

- $\quad$ For the studied PVSS, energy consumption was considered in the phases of: manufacture of the modules, assembly and installation of the system and operation (25 years assumed).

- Direct emissions from the photovoltaic module manufacturing process and emissions associated with the energy use for the manufacture of PVSS were accounted for.

- Data of emissions from transportation and the recycling process were also considered.

- The average data available in the literature for the energy values incorporated in the production of PVSS and the balance of system were used.

- All stages of the PVSS production process were carried out in China.

- $\quad$ The PVSS real electricity generation data for 1 year was used. The data from 2018 were the only publicly available during the time this study took place. Future work will look into the integration of longer historical datasets. For the projection of electricity generated by PVSS, an increase of losses by $0.7 \%$ per year was considered [31] to represent normal wear.

\subsection{PVSS Materials, Energy, and Carbon Inventory}

The primary energy necessary for the manufacture of photovoltaic systems was around $3418 \mathrm{MJ}_{\mathrm{p}} / \mathrm{m}^{2}$, considering the average of the values from 2005 to 2014 as found in the literature [32,34-37], which is equivalent to $317 \mathrm{kWh} / \mathrm{m}^{2}$ of electricity demand. In addition to the energy consumed for the manufacture of the photovoltaic modules, the energy used for the components of the balance of system (BOS) must also be considered, which includes the inverters, controllers, junction box, cabling, and support structure, to name few parts among others. Other studies have been carried out regarding BOS energy in different installation schemes, including Alsema et al. [38], Frankl et al. [39], Pacca and Silvaraman [34], Alsema and Wild-Scholten [37], and Alsema and Nieuwlaar [40].

Regarding the calculation of emissions related to the transport of photovoltaic systems, data were used regarding the power plants and the distance from the PV factory to each installation site. The maritime transport from the port of Shanghai in China to the port of Santos in Brazil was considered, and the road distance from the port of Santos to the place of installation of each PVSS in the study respectively. The emission factor used for maritime transport was $0.0179 \mathrm{~kg} \mathrm{CO}_{2} / \mathrm{tMn}$ [41]. Regarding the recycling process of the photovoltaic system, a value of $25 \mathrm{MJ} / \mathrm{m}^{2}$ [42] was used according to information from the 
installed PVSS areas and data from the literature, which contemplate the glass recycling process but did not include metals.

For the conversion of the primary thermal energy, required for the manufacture and installation of the PV panels, into electricity a generation efficiency index was applied for China [32] and Brazil [43], that was 0.22 for China [32], 0.625 for Brazil [43], respectively. An average factor of $0.33[35,44-46]$ was considered from the average primary energy consumption data applied in other countries. Literature data were used as a source of information for energy consumption. IEA and MCTIC [9,11] were the source of the emission factors.

\subsection{System Balance (GHG Emission Rate and EPBT from PVSS)}

For the calculation of the EPBT and the PVSS GHG emissions, the methodology used the following procedures [47]:

For the calculation of EPBT:

- Literature was the source of the energy values required in photovoltaic systems and their installation structures, given in $\mathrm{MJ}_{\mathrm{p}} / \mathrm{m}^{2}$;

- The area of each PVSS and the electricity values generated by each evaluated photovoltaic plant were collected from the Sunny portal [48], who is a supplier of photovoltaic systems.

- $\quad$ Equation (1) was used to calculate the EPBT.

For the estimation of the GHGe-rate:

- The values were converted from primary energy to electrical energy by using the total primary energy required for each PVSS $\left(\mathrm{MJ}_{\mathrm{p}}\right)$, expressed in $\mathrm{MJ}$ and then converted to $\mathrm{kWh}$.

- To calculate the GHG value from the electricity needed to manufacture and install the photovoltaic system, the emission factor of the electrical matrix of the country in which the photovoltaic system was manufactured, expressed in $\mathrm{g}^{\mathrm{CO}_{2-\mathrm{eq}}} / \mathrm{kWh}$, was used.

- Literature was the source of the estimated values of GHG emitted directly in the acquisition and manufacture of PVSS components, expressed in $\mathrm{g} \mathrm{CO}_{2 \text {-eq }} / \mathrm{m}^{2}$.

- Direct and indirect GHG emissions from the systems were combined.

- The electricity generation data for each analyzed photovoltaic system was used.

- Equation (2) was used to calculate the GHG emission rate in $\mathrm{g} \mathrm{CO}_{2-\mathrm{eq}} / \mathrm{kWh}$. Other parameters and considerations applied in this study:

- $\quad$ For the projection of electricity generated by PVSS in the year following the actual data collected (2018), an increase of losses by $0.7 \%$ per year was considered [31] to represent normal wear.

- To calculate emissions avoided during each plant's useful life, the total electricity generated per year (in MWh) was multiplied by the annual projected NIS emission factor (in $\mathrm{tCO}_{2} / \mathrm{MWh}$ ).

- The return time of the emissions generated in the manufacture of the systems was calculated using Equation (3).

\section{Case Study: PV Electricity Generation in Brazil}

Brazil is a country of great territorial extension with a wide variety of climates and variation in the annual solar irradiation at different regions, as shown in Figure 7. [49]. Its location in the tropics has potential for PV electricity generation throughout the year, especially at the areas located in the north-east and mid-west. Brazil receives average horizontal solar radiation in the range of 3.5 to $6 \mathrm{kWh} / \mathrm{m}^{2}$.day, which is higher than most European countries with an established PV installed capacity [49,50] (Table 1). 


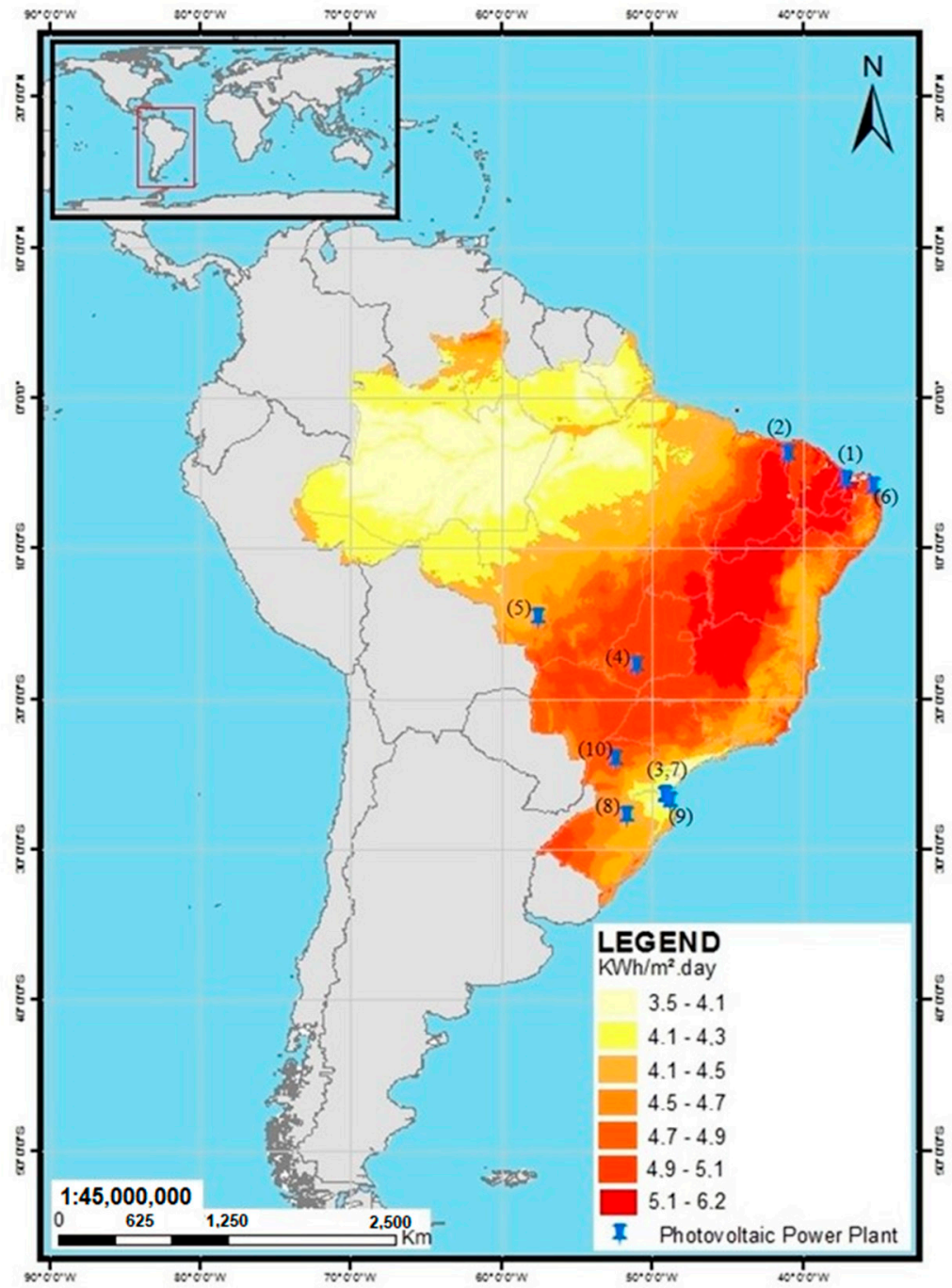

Figure 7. Annual average daily horizontal radiation. Pins show the location of the studied PV plants. Coordinate system: Datum Sirgas 2000. Data Source: [49,51].

Table 1. Daily solar irradiance and area by country.

\begin{tabular}{ccccc}
\hline Country & Average & $\begin{array}{c}\text { Minimum } \\
\left(\mathbf{k W h} / \mathbf{m}^{2} \text {. Day) }\right.\end{array}$ & Maximum & Area (Thousand. $\mathbf{k m}^{\mathbf{2}}$ ) \\
\hline Germany & 2.95 & 2.47 & 3.42 & 357.02 \\
France & 3.49 & 2.47 & 4.52 & 643.97 \\
England & 2.73 & 2.36 & 3.10 & 130.39 \\
Brazil & 5.50 & 4.25 & 6.75 & 8515.77 \\
\hline
\end{tabular}

The PVSS in this study are located in several Brazilian regions, from the south to the northeast of the country, representing the climate diversity of the country. PV plants with an installed capacity over $50 \mathrm{~kW}_{\mathrm{p}}$ and at least one full year of data available were chosen for the analysis. Their technical characteristics can be seen in Table 2. 
Table 2. Technical specifications of the evaluated photovoltaic plants.

\begin{tabular}{|c|c|c|c|c|c|c|c|c|c|c|}
\hline & (1) & (2) & (3) & (4) & (5) & (6) & (7) & (8) & (9) & (10) \\
\hline \multicolumn{11}{|l|}{ Location } \\
\hline City and state & Assú/RN & Ubajara/CE & $\begin{array}{c}\text { Jaraguá do } \\
\text { Sul/SC }\end{array}$ & Rio Verde/GO & $\begin{array}{c}\text { Campo Novo } \\
\text { do } \\
\text { Parecis/MT }\end{array}$ & $\begin{array}{l}\text { São José do } \\
\text { Mipibu/RN }\end{array}$ & $\begin{array}{c}\text { Jaraguá do } \\
\text { Sul/SC }\end{array}$ & $\begin{array}{l}\text { Cacique } \\
\text { Doble/RS }\end{array}$ & Itajaí/SC & $\begin{array}{c}\text { Campo } \\
\text { Mourão/PR }\end{array}$ \\
\hline $\begin{array}{c}\text { Annual } \\
\text { irradiation } \\
\left(\mathrm{kWh} / \mathrm{m}^{2} \text {.year }\right)\end{array}$ & 2154 & 2026 & 1469 & 1998 & 1952 & 2141 & 1469 & 1766 & 1586 & 1871 \\
\hline $\begin{array}{l}\text { Installed } \\
\text { PVcapacity }\end{array}$ & & & & & & & & & & \\
\hline $\begin{array}{c}(\mathrm{kWp}) \\
\text { Annual } \\
\text { electricity } \\
\text { generation }\end{array}$ & 108 & 51.5 & 77 & 65 & 140 & 72 & 70 & 52 & 77 & 52 \\
\hline $\begin{array}{l}\text { Annual Total } \\
\text { (MWh) }\end{array}$ & 173.8 & 67.5 & 75.3 & 82.4 & 161.7 & 106.4 & 71.3 & 55.2 & 98.8 & 59.0 \\
\hline $\begin{array}{l}\text { Annual Yield } \\
(\mathrm{kWh} / \mathrm{kWp})\end{array}$ & 1609 & 1312 & 977 & 1268 & 1156 & 1487 & 1015 & 1061 & 1280 & 1135 \\
\hline
\end{tabular}




\section{Results and Discussion}

\subsection{PV System EPBT and GHG Emission Rate}

This article aims to analyze public policies for the implementation of photovoltaic systems in a country with continental dimensions and an electrical matrix with a strong participation of renewables. In this way, the initial result of the life cycle analysis considers the real data of manufacture and installation of the studied PV systems, which were manufactured in China and installed in several Brazilian regions with different intensities of annual solar irradiation.

Additionally corroborating with the intention of analyzing national public policies, the electric matrix emission factor officially declared by the Brazilian government was considered, which has a long history of supplying the emission factor values of its electric matrix. Internationally reported data for China emission factor from the IEA were also used.

This section shows the results of the LCA in relation to the embodied energy and emissions (Table 3). The table shows the energy and carbon emissions payback for each of the photovoltaic plants installed over the wide Brazilian territory. Table 3 uses the official emission factors reported for Brazil (MCTIC) [11] and China (IEA) [9].

Table 3. Energy payback time and GHGe-rate for the solar PV power plants.

\begin{tabular}{|c|c|c|c|c|c|c|c|c|c|}
\hline \multirow[b]{3}{*}{ PVSS } & \multicolumn{3}{|c|}{ Energy } & \multicolumn{3}{|c|}{ Emissions $\mathrm{CO}_{2-\mathrm{eq}}$} & \multicolumn{3}{|c|}{ GHGe-Rate } \\
\hline & \multirow{2}{*}{$\begin{array}{c}\text { Required } \\
\text { (GJp) }\end{array}$} & \multirow{2}{*}{$\begin{array}{c}\begin{array}{c}\text { Annual } \\
\text { Converted }\end{array} \\
(\mathrm{GJp})\end{array}$} & \multirow{2}{*}{$\begin{array}{c}\text { Payback } \\
\text { (Years) }\end{array}$} & \multirow{2}{*}{$\begin{array}{l}\text { Avoided } \\
\left(\mathrm{tCO}_{2-\mathrm{eq}}\right) \\
\end{array}$} & \multirow{2}{*}{$\begin{array}{c}\text { Generated } \\
\left(\mathrm{tCO}_{2-\mathrm{eq}}\right) \\
\end{array}$} & \multirow{2}{*}{$\begin{array}{c}\text { Payback } \\
\text { (Years) }\end{array}$} & \multicolumn{3}{|c|}{ NIS } \\
\hline & & & & & & & $\left(\mathrm{gCO}_{2-\mathrm{eq}} / \mathrm{kWh}\right)$ & 2018 & 2020 \\
\hline 1 & 2695.06 & 1001.06 & 2.69 & 279.34 & 184.29 & 16.49 & 42.42 & & \\
\hline 2 & 1334.65 & 388.97 & 3.43 & 108.54 & 91.41 & 21.05 & 54.14 & & \\
\hline 3 & 2030.93 & 433.48 & 4.69 & 120.96 & 135.02 & 27.91 & 71.76 & & \\
\hline 4 & 1683.79 & 474.67 & 3.55 & 132.45 & 112.49 & 21.23 & 54.60 & & \\
\hline 5 & 3551.78 & 931.38 & 3.81 & 259.89 & 240.39 & 23.12 & 59.47 & & \\
\hline 6 & 1818.74 & 612.69 & 2.97 & 170.96 & 124.51 & 18.21 & 46.82 & 73.98 & 63.9 \\
\hline 7 & 1754.37 & 410.57 & 4.27 & 114.57 & 116.37 & 25.39 & 65.31 & & \\
\hline 8 & 1289.51 & 317.82 & 4.06 & 88.69 & 85.86 & 24.20 & 62.24 & & \\
\hline 9 & 1998.75 & 569.27 & 3.51 & 165.89 & 132.71 & 20.00 & 53.71 & & \\
\hline 10 & 1347.53 & 340.08 & 3.96 & 99.10 & 89.65 & 22.62 & 60.74 & & \\
\hline
\end{tabular}

In this study, it is suggested that even if PV systems do not have direct emissions during their operation, they have an impact in the global emissions balance associated to their lifecycle. In this way, they could be considered a "carbon import" that needs to be offset by the emissions saved from the grid where they are connected. This is the reason the study considers the life cycle "global" emissions of PV systems as a direct "local" emissions equivalent. If, in order to "decarbonize" the electrical matrix of a given country, it is necessary to import systems that during their life cycle emit more GHG in total than the direct emissions savings for the electrical matrix of the importing country, there is a potential to increase global emissions, despite locally, in the importing country, a false "decarbonization" occurs.

Figure 8 below shows the relationship between the emission of each analyzed photovoltaic system and the official emission factors of the Brazilian electric matrix for 2019 and its forecast for 2020. There is a forecast of maintaining low emission factors due to the penetration of more renewable systems, especially of large wind farms already contracted, in commissioning and beginning of operation. 
90.00

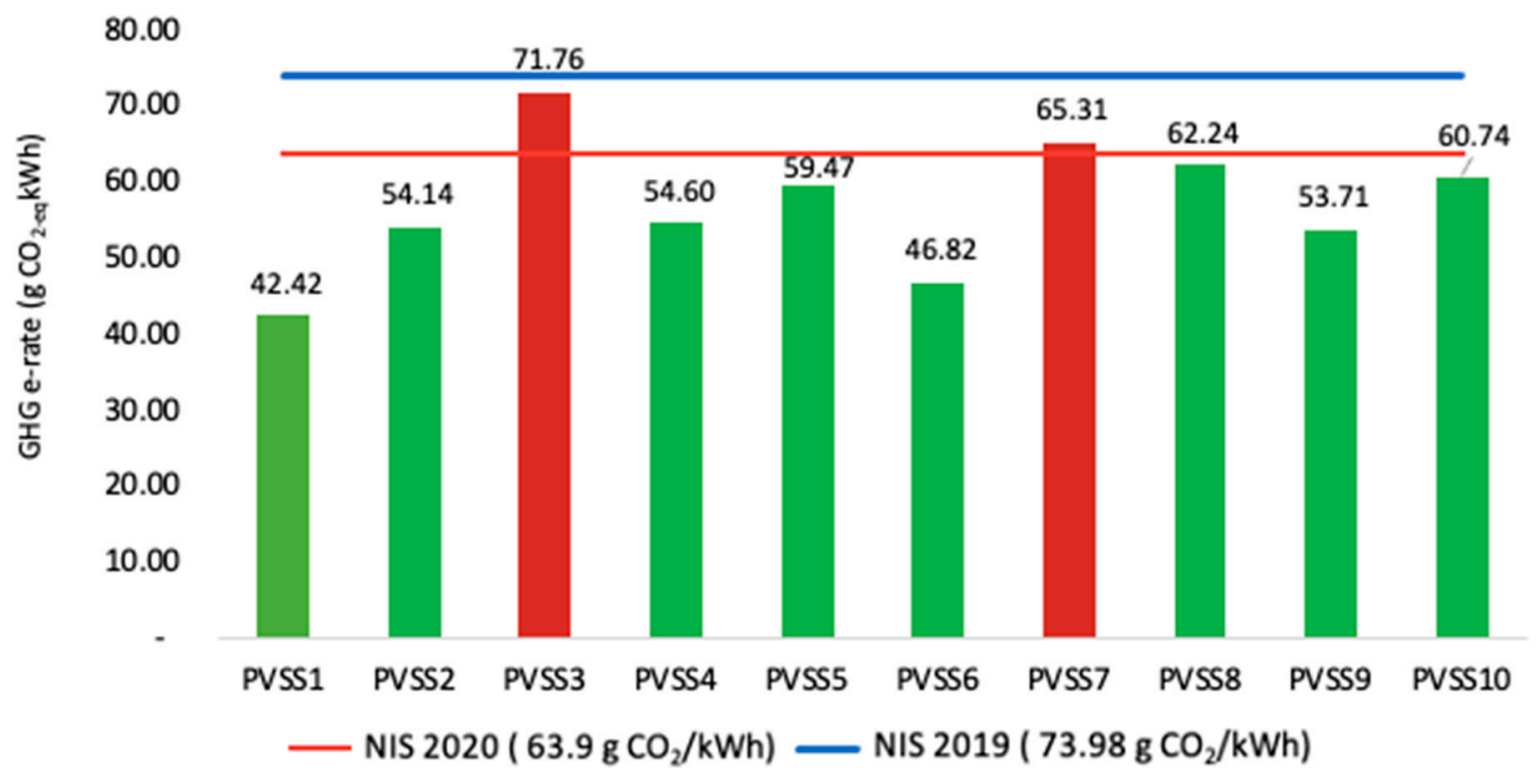

Note: Photovoltaic Solar Systems (PVSS) ; NIS (National Interconnected System) or GRID.

Figure 8. Comparison of the GHG rate results for PVSS in this study. Blue and red lines denote the emission factor of the Brazilian NIS of 2019 [11] and that projected for 2020 [10], respectively.

\subsection{Additional Analysis}

An additional analysis (Table 4) was carried out to verify the influence of the variation of the calculation parameters on the results: GHG rate of the electrical matrix both in the country where the photovoltaic systems were manufactured and, in the country, where the systems were installed.

Table 4. Energy payback time and GHGe-rate calculated with the upper range of the factors values. (Factors assumptions analysis).

\begin{tabular}{|c|c|c|c|c|}
\hline \multicolumn{5}{|c|}{ Emissions $\mathrm{CO}_{2-\mathrm{eq}}$} \\
\hline & Avoided & Generated & Payback & \\
\hline PVSS & $\left(\mathrm{tCO}_{2-\mathrm{eq}}\right)$ & $\left(\mathrm{tCO}_{2-\mathrm{eq}}\right)$ & (Years) & $\left(\mathrm{g} \mathrm{CO}_{2-\mathrm{eq}} / \mathrm{kWh}\right)$ \\
\hline 1 & 890.7 & 219.49 & 6.16 & 50.5 \\
\hline 2 & 346.1 & 108.69 & 7.85 & 64.4 \\
\hline 3 & 385.7 & 165.43 & 10.72 & 87.9 \\
\hline 4 & 422.3 & 137.1 & 8.12 & 66.6 \\
\hline 5 & 828.7 & 289.3 & 8.73 & 71.6 \\
\hline 6 & 545.1 & 148.1 & 6.79 & 55.7 \\
\hline 7 & 365.3 & 142.9 & 9.78 & 80.2 \\
\hline 8 & 282.8 & 105.0 & 9.28 & 76.1 \\
\hline 9 & 529.0 & 162.8 & 7.69 & 65.9 \\
\hline 10 & 316.0 & 109.8 & 8.68 & 74.4 \\
\hline
\end{tabular}

Note: In this complementary analysis, other emission factors from the electric matrix of Brazil and China were used.

In this analysis, for the emission factors, the results of studies by other authors [15,52] that obtained higher emission factors for China and Brazil were used as the data source. The reference values for the emission factor in China ranged from $0.637 \mathrm{~kg} \mathrm{CO}_{2} / \mathrm{kWh}$ (IEA [9]) to $0.821 \mathrm{~kg} \mathrm{CO}_{2} / \mathrm{kWh}$ [52] and the emission factor for the Brazilian electrical matrix ranged from $0.074 \mathrm{~kg} \mathrm{CO}_{2} / \mathrm{kWh}$ (MCTIC [11]) to $0.205 \mathrm{~kg} \mathrm{CO}_{2} / \mathrm{kWh}$ [15]. 
Figure 9 shows a comparison of the GHG emission results for different assumptions of the national grid emission factor. H1 shows the emission factor of the Brazilian electrical matrix from official data (MCTIC, [11]) and the emission factor of the Chinese electrical matrix (IEA, [9]). H2 shows the emission factor of the Brazilian electrical matrix calculated by Barros et al. ([15] and the emission factor of the Chinese electrical matrix as calculated by Lia et al. [52]).

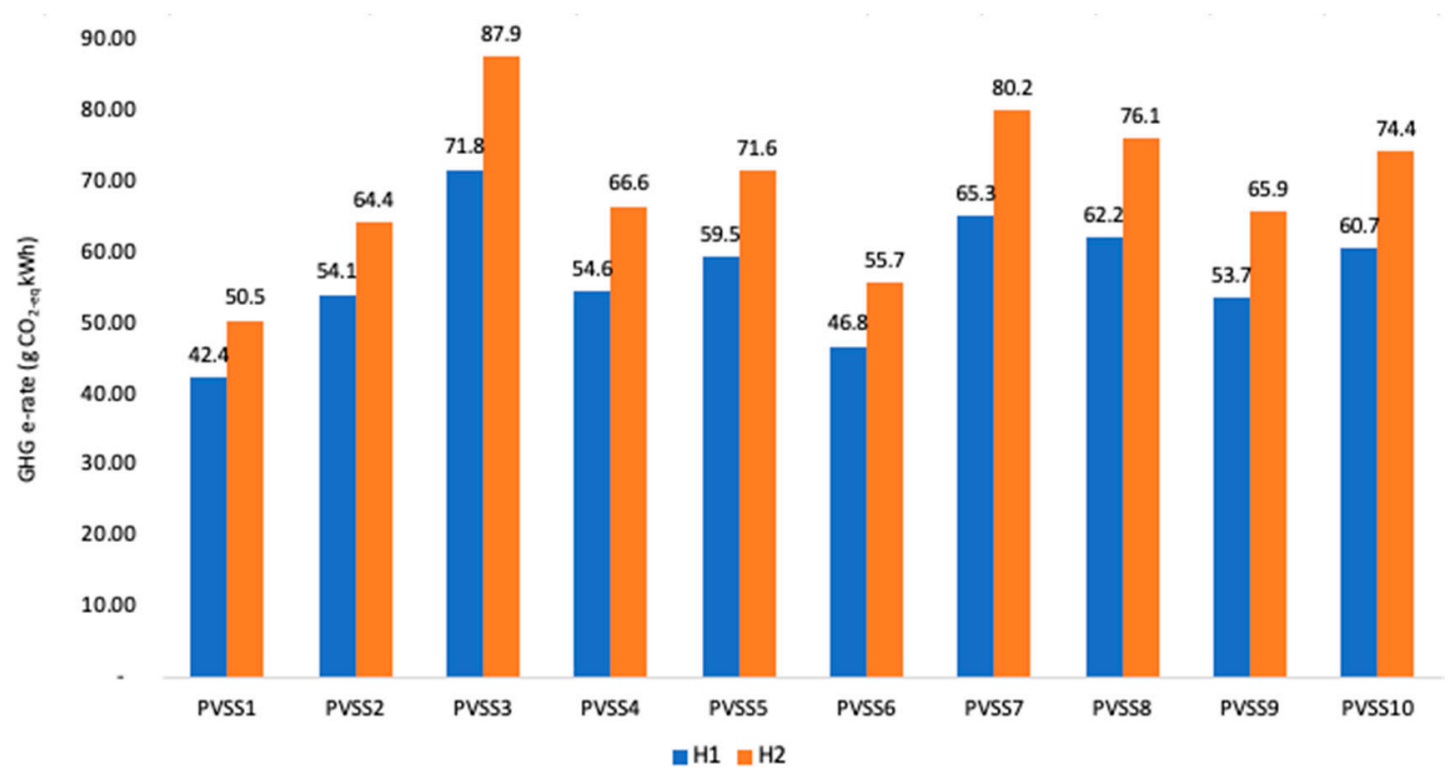

Figure 9. Comparison of the GHG emission results for different assumptions of the national grid emission factor.

In this direction, Figure 10 shows a comparison between payback emission time for different hypotheses adopted for national emission factors. $\mathrm{H} 1$ and $\mathrm{H} 2$ show the emission factors according to different sources of data as discussed in Figure 10 above.

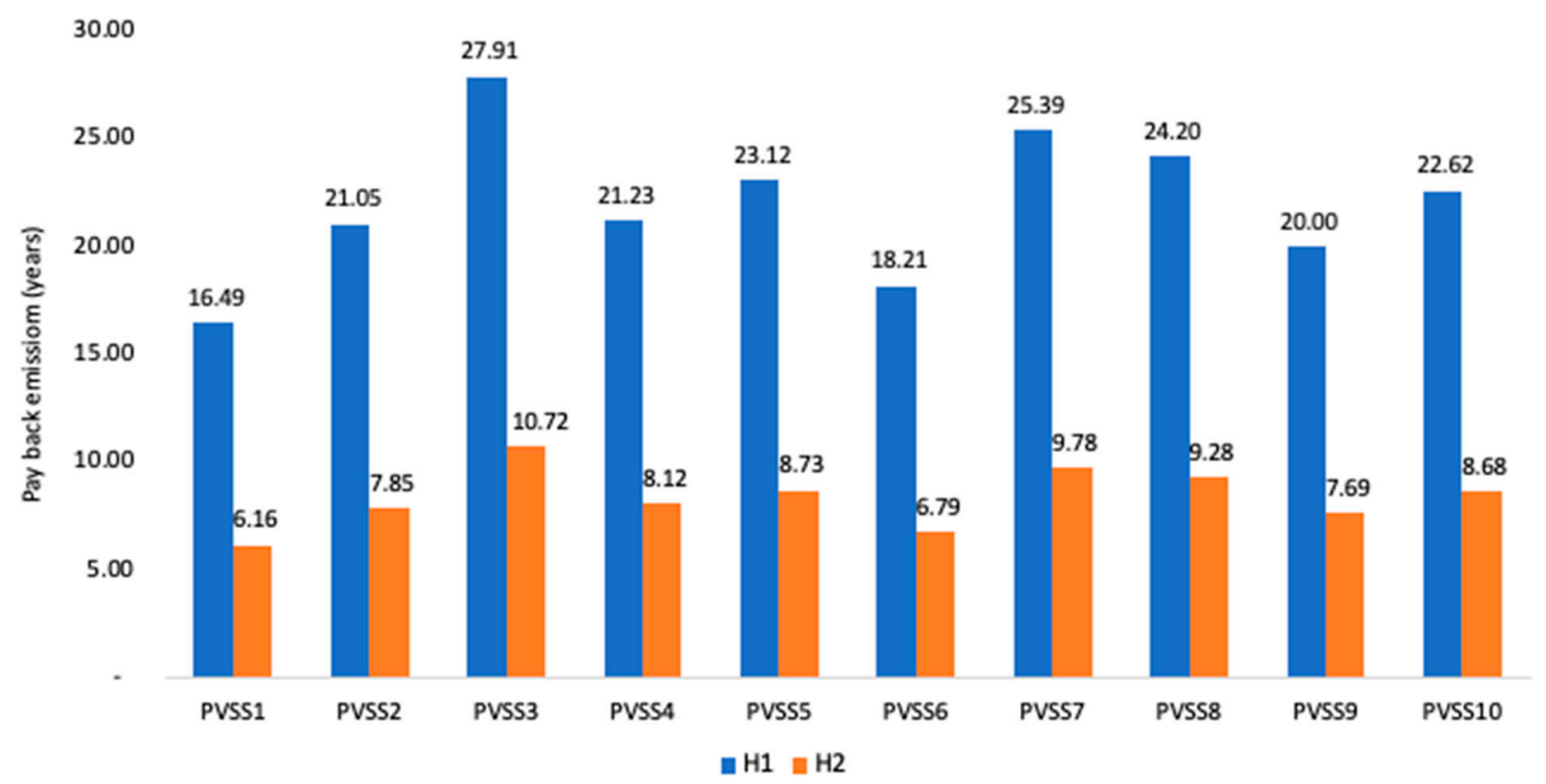

Figure 10. Comparison between payback emission time for different estimates of the national emission factors. 
With regard to $\mathrm{CO}_{2-\text { eq }}$ emissions, it can be seen in the results of Table 4 that the emission return time decreases considerably when compared to Table 3 . This occurs because in the simulated hypothesis (the one in Table 4), the emission factor of the Brazilian matrix considered is more than twice the official data, thus the direct emissions avoided by the use of the installed photovoltaic systems, during the whole useful life is much higher. On the other hand, with an increase of about $29 \%$ in the emission factor data of the Chinese electrical matrix, the GHG emissions during the lifetime of the photovoltaic systems under this hypothesis are even greater than the results in Table 3. This article prioritizes in its analysis and conclusions the focus on official data as it intends to discuss the effect of national renewable incentives policies on global net GHG reductions. Specifically, when the policies are implemented in countries with a large share of renewable sources as in the case of Brazil.

\subsection{Discussion}

The results indicate an estimated payback period for the embodied energy in the range of 3 to 5 years. The calculated payback periods in this study were about 1 year longer than those in previous studies [32,53-59]. That can be explained by the different network efficiency factor used in the relevant literature. This study assumed an efficiency factor of 0.625 for Brazil, 0.625 for USA, and 0.327 for Europe approximately. Interestingly, an EPBT of only 5 years shows that the energy required for the manufacture and installation of the PV systems in Brazil will be recovered in a relatively short period when compared to the systems' useful life of 25 years, and at most cases in less than 10 years that is the threshold when an investment is considered financially viable usually.

The different annual yield $\left(\mathrm{kWh} / \mathrm{kW}_{\mathrm{p}}\right)$ in different locations in Brazil impacts the respective EPBT and GHGe-rate of the studied systems. The variations in generation are mainly the result of variations in solar irradiation among the locations and the efficiency of the PV modules. In addition, there are possible differences in the design and implementation of the PVSS (i.e., orientation and inclination of panels). It is observed that PVSS 3 and PVSS 7 are south in the east coast of Brazil, where average solar irradiation is about $30 \%$ lower than the location of PVSS 1. These two systems had the lowest annual generation output, PVSS 3 (977 kWh/kW $)$ and PVSS $7\left(1015 \mathrm{kWh} / \mathrm{kW}_{\mathrm{p}}\right)$. This represents 37\% and $39 \%$ respectively less annual generation when compared with PVSS 1 (Figure 11). Those differences in generation and their impact on the EPBT and GHGe-rate had already been a concern and limitation of studies carried out with only one PVSS installed in a single location such as a previous study in the Brazilian state of Rio Grande do Norte [47].

The unit cost of kWh generated during the PVSS useful life (25 years) was not estimated by this study because there were not any data available regarding the cost of the studied PVSS. The average life cycle emission rate calculated for the 10 PVSSs was $53.59 \mathrm{~g} \mathrm{CO}_{2-\mathrm{eq}} / \mathrm{kWh}$, being lower than the projected rate for the electric matrix in 2020, which is $63.9 \mathrm{~g} \mathrm{CO}_{2} / \mathrm{kWh}$. The carbon intensities of PVSS 3 and PVSS 7 are the only ones higher than the $63.9 \mathrm{~g} \mathrm{CO}_{2} / \mathrm{kWh}$ projection mark. However, this is an indication of the considerations required regarding the emissions balance when PV systems are installed in certain locations, as in reality they may not contribute positively to the reduction of net total GHG emissions in a national and global level. This net negative contribution to emissions is exacerbated at countries with a large existing share of renewables electricity generation and as grid carbon intensity becomes lower.

The emission rates in this study ranged from 42.42 to $71.76 \mathrm{~g} \mathrm{CO}_{2-\mathrm{eq}} / \mathrm{kWh}$. These values are in agreement with the results of previous studies such as those carried out by Yue et al. and Kommalapi [60]. Approximately $80 \%$ of the total $\mathrm{CO}_{2 \text {-eq }}$ emissions of the PVSS in this study originate from the energy required for the manufacture and installation of the PVSS. This result is indicative of the reliance in Chinese products and China's current high carbon intensity in manufacture. Thus, it becomes apparent that the origin of the PV panels plays an important role in achieving any net-carbon reduction global targets despite the size of investment in renewable energy resources. 


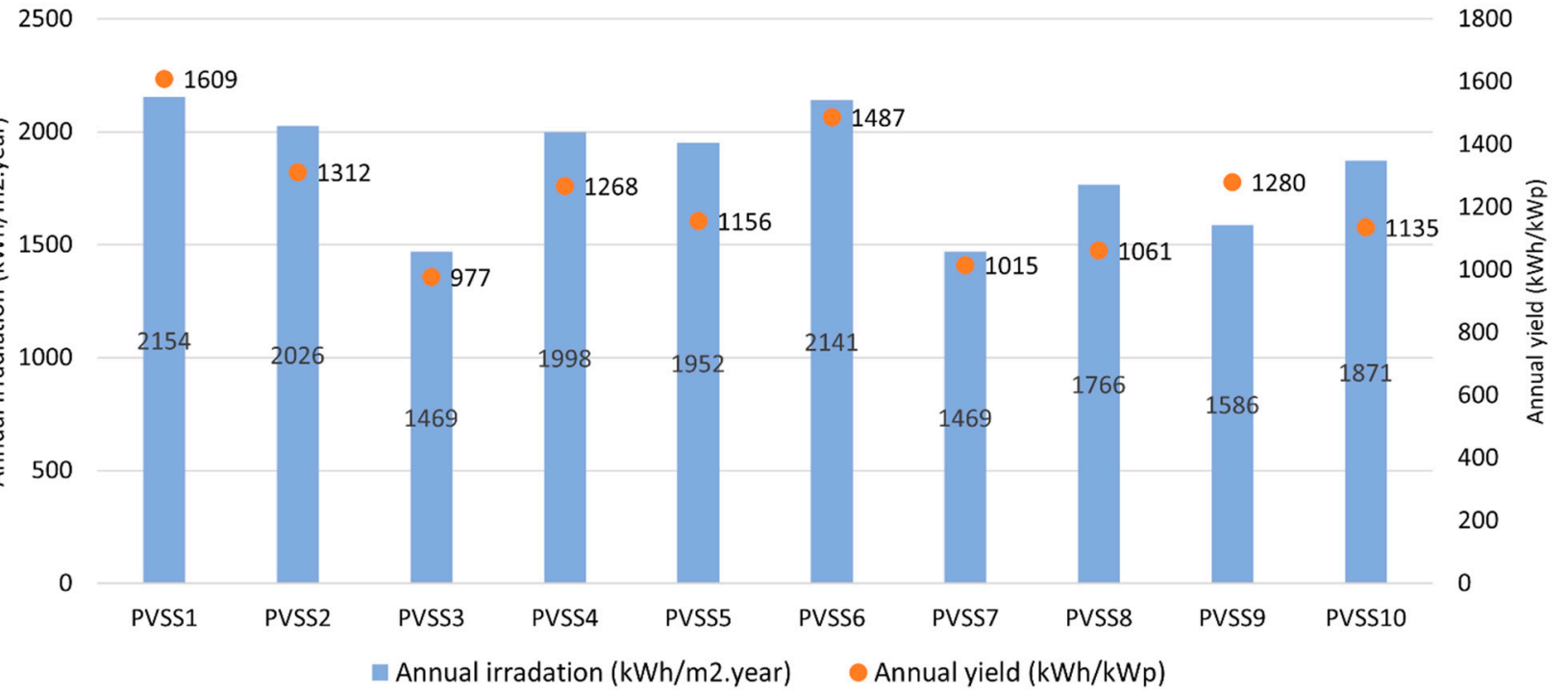

Figure 11. Comparison of annual irradiation with PV electricity generation.

Some limitations were found in this research, which could be addressed in future work:

- There is only data available for one year of electricity generation of the systems studied and the outputs were projected for the remaining 24 years of useful life despite any possible upgrades or downgrades during this period;

- For the calculation of the emissions avoided by the installation of the systems, it was considered that the emission factor of the matrix remains constant and equal to 2020 levels;

- $\quad$ Future work, if hourly PV generation data are available, could perform a comparative analysis with hourly data from NIS emission or marginal factors.

\section{Conclusions}

This study presents a life cycle analysis of photovoltaic systems representative of the different operational conditions in regions across Brazil. It was found that the average energy payback time is between 3 and 5 years of operation. This result shows the feasibility and viability of such investments in the Brazilian context. Despite the complexity and intensive energy requirements for manufacture and the infrastructure needed for installation, most PV systems in Brazil are expected to return the energy and life cycle emissions from manufacture and installation within a short payback period.

This is usually the first analysis to advocate the adoption of a power generation technology. However, the energy sector, as it is discussed in the introduction, is historically one of the main producers of greenhouse gases. Renewable energy systems that produce more carbon emissions during their life cycle than those avoided during their operational lifetime could in reality aggravate global climate change, generating a vicious cycle of increasing energy demand to compensate, mitigate, and adapt to climate change. Therefore, it is essential to not only analyze the energy output and cost efficiency, but also integrate in the analysis the environmental aspects and the full life cycle embodied carbon involved with the adoption of a specific energy system too.

This study assessed the cradle to grave life cycle of PVSS from China installed in Brazil. China is the main world producer of photovoltaic systems whereas Brazil is a country with an electrical matrix that is already primarily based on renewable sources. In that case, it was found that the life cycle carbon emissions payback time exceeded the life expectancy of the PV systems in 2 out of the 10 installed plants assessed in this study. According to the results, these two plants will not manage to offset their embodied carbon emissions, as they generate electricity in the horizon of 25 years of their useful life with a carbon intensity still 
higher than the 2020 projected emission factor for the Brazilian electrical matrix. This is mainly a result of the location of the PV systems and the offset of emissions (emissions avoidance) from a grid with very low carbon intensity as it relies mainly in hydropower.

In countries like Brazil, this result, where PV systems will likely not compensate for their embodied carbon emissions during their operational lifetime, leads to the realization that the adoption of PVSS requires further careful analysis of the environmental impacts related to their life cycle and there are instances where they could even have a negative impact in net emissions at national and global level. It is however noted that Brazil has in general a very high solar radiation potential but at the same time a very low grid carbon intensity.

It is suggested, according to the findings, that public policies of unrestricted, unconditional stimulus to photovoltaic systems investment might not help towards reducing emissions at countries with a low carbon emission electric matrix and at global level. Such policies are often copied from other, notably developed countries, where the conditions of use and the carbon offsets are significantly different. Those policies when horizontally applied without appropriate environmental analysis, as proposed by this study, can actually result in "carbon imports", even worsening the total net emissions balance in the long term. That is also something to consider for other countries as the carbon intensity of their grids will start reducing at levels similar to Brazil's.

The northeast region in Brazil comprises most areas of high solar radiation and unfortunately coincides with the least developed regions of the country. A national policy to encourage PV capacity installation at the regions with the greatest solar radiation potential needs to be implemented, with incentives to prioritize installation at the areas with greater application efficiency.

In the near future, the manufacture procedures, the carbon intensity associated with Chinese production lines and the origin of PV panels will play an important role to the reduction of net global GHG emissions. Future research could examine the scenarios of sourcing the PV panels locally or from other than China countries but cost considerations and availability should be also considered among other factors. Current PV manufacture in Brazil focuses only on final panel assembly processes, and other less energy intensive processes than the manufacture. The most energy-intensive processes occur in other countries, mainly in China. The higher cost of Brazilian electricity, labor, and local taxes contributes to outsource manufacturing. Local production is still insipient to serve the national market.

The manufacture of photovoltaic systems in countries with lower emission factors, as well as the adoption of current PV panels in countries with electrical matrix with a high emission factor, could help to achieve the necessary compensation of lifecycle-related carbon emissions and contribute further to the reduction of net global GHG emissions.

Author Contributions: Data curation, investigation, and methodology, G.C.d.L. and A.L.L.T. Writing-original draft, G.C.d.L., A.L.L.T. and L.B. Writing-review and editing, L.B. All authors have read and agreed to the published version of the manuscript.

Funding: This research received no external funding.

Institutional Review Board Statement: not applicable.

Informed Consent Statement: not applicable.

Data Availability Statement: not applicable.

Acknowledgments: The authors would like to thank to SMA Brazil for allowing the use of data from photovoltaic systems using its supervisory system.

Conflicts of Interest: The authors declare no conflict of interest.

\section{References}

1. IEA. IEA Sankey Diagram. Available online: https://www.iea.org/sankey/ (accessed on 27 October 2020). 
2. Evans, S.; Pearse, R. Mapped: The world's Coal Power Plants in 2020. Available online: https:/ /www.carbonbrief.org/mappedworlds-coal-power-plants (accessed on 30 September 2020).

3. Oak Ridge National Laboratory. Carbon dioxide Information Analysis; Oak Ridge National Laboratory: Oak Ridge, TN, USA, 2017.

4. Carbon Footprint. Carbon Footprint Country Specific Electricity Grid Greenhouse Gas Emission Factors; Carbon Footprint: Hampshire, UK, 2019.

5. IRENA. Renewable Capacity Statistics 2020 International Renewable Energy Agency (IRENA); IRENA: Abu Dhabi, United Arab Emirates, 2020.

6. MCTIC. Estimativas Anuais de Emissões de Gases de Efeito Estufa no Brasil, 5th ed.; MCTIC: Brasília, Brazil, 2020; ISBN 9788588063914.

7. SEEG Brasil Emissões Totais I SEEG-Sistema de Estimativa de Emissão de Gases. Available online: http:/ / plataforma.seeg.eco.br/ total_emission (accessed on 28 January 2021).

8. IEA. Electricity Information: Overview; IEA: Paris, France, 2019.

9. IEA. $\mathrm{CO}_{2}$ Emissions from Fuel Combustion 2019 Highlights; IEA: Paris; France, 2019.

10. EPE. Cartilha EPE-Riomais20. In Proceedings of the Conferência para o Clima Rio+20; Rio de Janeiro, Brazil, $2012 ;$ p. 4.

11. MCTIC. Fatores de Emissão de CO2 do Sistema Interligado Nacional do Brasil. Available online: https: / /antigo.mctic.gov.br/ mctic/opencms/ciencia/SEPED/clima/textogeral/emissao_corporativos.html (accessed on 26 January 2021).

12. EPE. PDE 2027-Plano Decenal de Energia; EPE: Rio de Janeiro, Brazil, 2019.

13. Dale, A.; Pereira de Lucena, A.; Marriott, J.; Borba, B.; Schaeffer, R.; Bilec, M. Modeling Future Life-Cycle Greenhouse Gas Emissions and Environmental Impacts of Electricity Supplies in Brazil. Energies 2013, 6, 3182-3208. [CrossRef]

14. Balcar, P. Emissões de Gases de Efeito Estufa em Reservatórios de Centrais Hidrelétricas; MME: Rio de Janeiro, Brazil, 2014.

15. Barros, M.; Piekarski, C.; de Francisco, A. Carbon Footprint of Electricity Generation in Brazil: An Analysis of the 2016-2026 Period. Energies 2018, 11, 1412. [CrossRef]

16. EPE. PDE2026-Plano Decenal de Energia; EPE: Brasília, Brazil, 2017.

17. Ecoinvent Data Base. Available online: https://www.ecoinvent.org/database/database.html (accessed on 24 July 2020).

18. Mma, M.; Do, M.A. Federative Republic of Brazil Intended Nationally Determinaded Contribution towards Achieving the Object of the United Nations Framework Convention on Climate Change; Brazil'sInitial National Communication: Brasília, Brazil, 2015.

19. ANEEL. Resolução Normativa no 482; ANEEL: Rio de Janeiro, Brazil, 2012.

20. ANEEL. Resolução Normativa no 687; ANEEL: Rio de Janeiro, Brazil, 2015.

21. ANEEL. Resolução Normativa n. 786/2017; ANEEL: Rio de Janeiro, Brazil, 2017.

22. ANEEL. Nota Técnica no 0056/2017; ANEEL: Rio de Janeiro, Brazil, 2017.

23. GREENER. Estudo Estratégico-Mercado Fotovoltaico de Geração Distribuída-2 Semestre de 2018; GREENER: São Paulo, Brasil, 2018.

24. SOLARTAIC Net Metering e Feed In. Available online: https:/ /www.solarvoltenergia.com.br/blog/net-metering-e-feed-insaiba-o-que-sao-e-como-funcionam/ (accessed on 7 April 2020).

25. Pinto, A.; Zilles, R. Reactive power excess charging in grid-connected PV systems in Brazil. Renew. Energy 2014, 62, 47-52. [CrossRef]

26. Peng, J.; Lu, L.; Yang, H. Review on life cycle assessment of energy payback and greenhouse gas emission of solar photovoltaic systems. Renew. Sustain. Energy Rev. 2013, 19, 255-274. [CrossRef]

27. Löfgren, B.; Tillman, A.M.; Rinde, B. Manufacturing actor's LCA. J. Clean. Prod. 2011, 19, 2025-2033. [CrossRef]

28. Fthenakis, V.M.; Kim, H.C. Photovoltaics: Life-cycle analyses. Sol. Energy 2011, 85, 1609-1628. [CrossRef]

29. Mann, S.A.; de Wild-Scholten, M.J.; Fthenakis, V.M.; van Sark, W.G.; Sinke, W.C. The energy payback time of advanced crystalline silicon PV modules in 2020: A prospective study. Prog. Photovolt. Res. Appl. 2014, 22, 1180-1194. [CrossRef]

30. Barros, M.V.; Salvador, R.; Piekarski, C.M.; de Francisco, A.C.; Freire, F.M.C.S. Life cycle assessment of electricity generation: A review of the characteristics of existing literature. Int. J. Life Cycle Assess. 2020, 25, 36-54. [CrossRef]

31. Fthenakis, V.M.; Frischknecht, R.; Raugei, M.; Kim, H.C.; Alsema, E.; Held, M.; de Wild Scholten, M. Methodology Guidelines on Life Cycle Assessment of Photovoltaic Electricity; IEA: Paris, France, 2011; ISBN 978-3-906042-38-1.

32. Yue, D.; You, F.; Darling, S.B. Domestic and overseas manufacturing scenarios of silicon-based photovoltaics: Life cycle energy and environmental comparative analysis. Sol. Energy 2014, 105, 669-678. [CrossRef]

33. Nieuwlaar, E.; Alsema, E. Envorimental aspects of PV power systems. In Proceedings of the IEA PVPS Task 1 Workshop; IEA: Utrecht, The Netherlands, 1997; pp. 25-27.

34. Pacca, S.; Sivaraman, D.; Keoleian, G.A. Parameters affecting the life cycle performance of PV technologies and systems. Energy Policy 2007, 35, 3316-3326. [CrossRef]

35. Alsema, E.A.; De Wild-Scholten, M.J. Environmental Impacts of Crystalline Silicon Photovoltaic Module Production. In CIRP Intern. Conf. on Life Cycle Engineering; Materials Research Society: Leuven, Belgium, 2006.

36. Wild-Scholten, M. Energy payback times of PV modules and systems; Workshop Photovoltaic: Köln, Germany, 2009 ; pp. $26-27$.

37. Alsema, E.A.; Wild-Scholten, M.J. Reduction of the Environmental Impacts in Crystalline Silicon Module Manufacturing; WIP-Renewable Energies: Munich, Germany, 2007.

38. Alsema, E.A.; Frankl, P.; Kato, K. Energy Pay-Back Time of Photovoltaic Energy Systems: Present Status and Prospects. In 2nd World Conference on Photovoltaic Solar Energy Conversion; Utrecht University Repository: Viena, Austria.

39. Frankl, P.; Masini, A.; Gamberalet, M.; Toccacelift, D.; Toccacelit, D. Simplified Life-Cycle Analysis of PV Systems in Buildings: Present situation and future trends. Prog. Photovolt. Res. Appl. 1998, 6, 137-146. [CrossRef] 
40. Alsema, E.; Nieuwlaar, E. Energy viability of photovoltaic systems. Energy Policy 2000, 28, 999-1010. [CrossRef]

41. ODFJELL. Environmental Initiatives in ODFJELL; ODFJELL: Bergen, Norway, 2015.

42. Alsema, E. Energy requirements of thin-film solar cell modules-A review. Renew. Sustain. Energy Rev. 1998, 2, $387-415$. [CrossRef]

43. Rupp, R.F.; Lamberts, R. Relatório: Fatores de conversão de energia elétrica e térmica em energia primária e em emissões de dióxido de carbono a serem usados na etiquetagem de nível de eficiência energética de edificações; UFSC: Florianópolis, Brazil, 2017.

44. Fthenakis, V.; Kim, H.C. Energy Use and Greenhouse Gas Emissions in the Life Cycle of CdTe Photovoltaics. In Symposium GLife-Cycle Analysis Tools for "Green" Materials and Process Selection; Cambridge University Press: Cambridge, UK, 2005; Volume 895, pp. 1-6.

45. EIA. Annual Energy Review 2003; EIA-Energy Information Administration: Washington, DC, USA, 2003.

46. Raugei, M.; Bargigli, S.; Ulgiati, S. Life cycle assessment and energy pay-back time of advanced photovoltaic modules: CdTe and CIS compared to poly-Si. Energy 2007, 32, 1310-1318. [CrossRef]

47. Constantino, G.; Freitas, M.; Fidelis, N.; Pereira, M. Adoption of Photovoltaic Systems Along a Sure Path: A Life-Cycle Assessment (LCA) Study Applied to the Analysis of GHG Emission Impacts. Energies 2018, 11, 2806. [CrossRef]

48. Sunny Portal Publicly Available PV System-Sunny Portal. Available online: https://www.sunnyportal.com/Templates/ PublicPagesPlantList.aspx (accessed on 16 June 2020).

49. Pereira, E.B.; Martins, F.R.; Gonçalves, A.R.; Costa, R.S.; Lima, F.L.; Rüther, R.; Abreu, S.L.; Tiepolo, G.M.; Pereira, S.V.; Souza, J.G Atlas brasileiro de energia solar; INPE, Ed.; 2a; INPE: São José dos Campos, Brazil, 2017.

50. Tiba, C. Banco de dados terrestres: Atlas Solarimétrico do Brasil; UFPE, Ed.; UFPE: Recife, Brazil, 2000.

51. INPE (Instituto Nacional de Pesquisas Espaciais). Banco de Dados do Atlas Solar Brasileiro de Energia Solar. Available online: http:/ /labren.ccst.inpe.br/ (accessed on 27 June 2018).

52. Xin, L.; Konstantinos, J.; Chalvatzisa, D.P. China's electricity emission intensity in 2020 - An analysis at provincial level. Energy Procedia 2017, 142, 2779-2785. [CrossRef]

53. Alsema, E.A. Energy pay-back time and $\mathrm{CO}_{2}$ emissions of PV systems. Prog. Photovoltaics Res. Appl. 2000, 8, 17-25. [CrossRef]

54. Breyer, C.; Koskinen, O.; Blechinger, P. Profitable climate change mitigation: The case of greenhouse gas emission reduction benefits enabled by solar photovoltaic systems. Renew. Sustain. Energy Rev. 2015, 49, 610-628. [CrossRef]

55. Hondo, H. Life cycle GHG emission analysis of power generation systems: Japanese case. Energy 2005, 30, 2042-2056. [CrossRef]

56. Fthenakis, V.; Alsema, E. Photovoltaics energy payback times, greenhouse gas emissions and external costs: 2004-early 2005 status. Prog. Photovoltaics Res. Appl. 2006, 14, 275-280. [CrossRef]

57. Lenzen, M. Life-Cycle Energy Balance and Greenhouse Gas Emissions of Nuclear Energy in Australia. 2008. Energy Convers. Manag. 2008, 49, 2178-2199. [CrossRef]

58. Stoppato, A. Life cycle assessment of photovoltaic electricity generation. Energy 2008, 33, 224-232. [CrossRef]

59. Ito, M.; Komoto, K.; Kurokawa, K. Life-cycle analyses of very-large scale PV systems using six types of PV modules. Curr. Appl. Phys. 2010, 10, S271-S273. [CrossRef]

60. Kommalapati, R.; Kadiyala, A.; Shahriar, M.; Huque, Z. Review of the Life Cycle Greenhouse Gas Emissions from Different Photovoltaic and Concentrating Solar Power Electricity Generation Systems. Energies 2017, 10, 350. [CrossRef] 